\title{
ELECTROPHORETIC STUDIES OF THE SERUM PROTEINS IN BILIARY CIRRHOSIS
}

\author{
By KENNETH STERLING ${ }^{1}$ AND WILLIAM E. RICKETTS
}

(From the Frank Billings Medical Clinic, Department of Medicine, The University of Chicago, Chicago, Ill.)

(Received for publication June 8, 1949)

Although the serum proteins in diseases of the liver have been studied by the electrophoretic method by many investigators, few references have been made to biliary cirrhosis (1-3). Since a systematic study has not as yet appeared, the present investigation of ten cases of obstructive biliary cirrhosis was undertaken.

\section{METHODS}

Electrophoretic runs were performed with standard apparatus and technique, the experimental details having been reported previously (4). The buffer was sodium diethylbarbiturate (veronal) of $\mathrm{pH} 8.6$ and ionic strength 0.1 .

In the estimation of the fractions as per cent of the serum proteins both ascending and descending patterns were used, the areas being divided by ordinates from the nadirs between peaks to the base line. The quantities of the fractions as grams per cent represent the products $(4,5)$ of the percentages and the total proteins from the conventional Kjeldahl method, using a nitrogen factor of 6.25. Such a method of computation involves the assumptions that the specific refractive increments and the nitrogen contents of the various protein fractions are identical. These assumptions which have been generally employed as first approximations must be modified somewhat in view of the quantitative studies of Armstrong and colleagues $(6,7)$. In practice the errors thus introduced appear ordinarily no greater than others inherent in the electrophoretic method. However, where there is considerable increase in the lipids associated with the beta-globulin complex, the nitrogen content of this fraction is low in comparison with its refractive increment which determines the size of the peak in the electrophoretic diagram. In such a circumstance, which occurred in some of the cases of the present series, the errors in computing the absolute concentrations of the protein fractions may become appreciable. On the other hand, the accuracy of the values for the relative proportions of the fractions (as per cent of the serum proteins) should not be seriously affected.

The tests of hepatic function were performed by the usual methods as previously described (4), alkaline phosphatase being reported in Bodansky units. Cholesterol

\footnotetext{
1 Present address: Department of Medicine, Harvard
} Medical School, Boston, Mass. and cholesterol esters were determined by the method of Schoenheimer and Sperry (8).

Ether extraction of the serum was carried out in one case by performing three extractions with redistilled diethyl ether, shaking thoroughly before each separation. The procedure was carried out in a cold room at $4^{\circ} \mathrm{C}$. The ether layer acquired the coloration of the serum, the hue being progressively less intense on successive extractions so that in the third, the ether layer was almost colorless.

\section{CASE MATERIAL}

The present study comprises ten cases of obstructive biliary cirrhosis. In all patients cholelithiasis had been present and cholecystectomies had been performed. All had been intensely jaundiced or were still jaundiced at the time of study. In six cases (L. S., L. H., K. V., M. G., W. H., and T. O.) development of biliary cirrhosis followed cholecystectomy, and four of these patients (L. S., L. H., W. H., and T. O.) had subsequent laparotomies in the attempt to repair a severely stenosed common duct. In four cases (F. F., M. E., M. F., and C. M.) biliary cirrhosis was already present at the time of cholecystectomy and hence could not be attributed to surgical trauma to the common duct.

The diagnosis was confirmed histologically from tissue obtained at laparotomy or by needle (Vim Silverman) biopsy of the liver in eight of the ten cases. The other two (M. G. and W. H.) were clinically typical cases, and in one of them (W. H.) an enlarged bile-stained liver was observed at three laparotomies for repair of the severely stenosed common duct.

The series has been confined to cases of biliary cirrhosis of the obstructive type, other etiologies such as parasitic infestation, etc. being excluded. No cases of essential xanthomatosis were studied.

\section{RESULTS}

Typical electrophoretic patterns are illustrated in Figure 1 and the data on the serum proteins as well as the tests of hepatic function are listed in Table I, roughly in order of increasing deviation from normal serum protein composition. The normal controls have been reported previously (4).

The electrophoretic analyses revealed diminutions of the serum albumin fractions in all cases 
TABLE I

Bromsulfalein tests on the two patients with normal serum bilirubin values, W. H. and M.F., revealed 3 per cent and 48 per cent retention respectively

BITTARY CIRFEOSTS

\begin{tabular}{|c|c|c|c|c|c|c|c|c|c|c|c|c|c|c|c|c|c|c|c|c|c|c|}
\hline \multirow{3}{*}{ Pationt } & \multicolumn{11}{|c|}{ Eloctrophorot10 date } & \multicolumn{4}{|c|}{ How sodium sulfato } & \multicolumn{7}{|c|}{ Toets of hopat10 runotion } \\
\hline & \multicolumn{5}{|c|}{ per cont } & \multicolumn{5}{|c|}{ exems por cont } & \multirow[b]{2}{*}{$A / G$} & \multirow[b]{2}{*}{$A / G$} & \multicolumn{3}{|c|}{ Exams por cont } & \multirow{2}{*}{\multicolumn{2}{|c|}{ 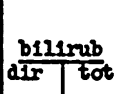 }} & \multirow[b]{2}{*}{$\operatorname{coph}$} & \multirow[b]{2}{*}{ thom } & \multirow{2}{*}{$\frac{\text { alk }}{\text { phos }}$} & \multirow[b]{2}{*}{ obol } & \multirow{2}{*}{$\begin{array}{l}\text { ahol } \\
\text { pet }\end{array}$} \\
\hline & Alb & $\alpha_{1}$ & $\alpha_{2}$ & $\beta$ & $\gamma$ & Alb & $\alpha_{1}$ & $\alpha_{2}$ & $\beta$ & $\gamma$ & & & Alb & Clob & Tot & & & & & & & \\
\hline พ.H. & 54.6 & 5.0 & 9.0 & $|17.7|$ & 13.7 & 3.78 & 0.35 & 0.62 & 1.22 & 0.95 & 1.20 & 2.04 & 4.64 & 2.28 & 6.92 & 0.5 & 0.9 & nog. & 2.7 & 2.3 & 270 & 205 \\
\hline M.T. & 44.8 & 5.4 & 10.2 & 16.3 & 23.3 & 3.40 & 0.42 & 0.78 & 1.24 & 2.77 & 0.81 & 2.33 & 4.34 & 3.26 & 7.60 & 0.6 & 0.9 & 24 & 6.9 & 35.1 & 230 & 172 \\
\hline T.0. & 42.1 & 6.6 & 23.3 & 27.9 & 10.1 & 2.69 & 0.42 & 0.85 & 1.79 & 0.65 & 0.73 & 1.91 & 4.20 & 2.20 & 6.40 & 13.4 & 18.2 & nog. & 1.1 & - & 355 & 155 \\
\hline M.G. & 47.9 & 4.1 & 9.2 & 20.3 & 28.5 & 3.44 & 0.29 & 0.66 & 1.46 & 1.33 & 0.92 & 1.37 & 4.15 & 3.03 & 7.18 & 1.0 & 1.5 & $3+$ & 6.2 & 6.8 & 255 & 188 \\
\hline C.M. & 40.8 & 7.2 & 16.1 & 15.7 & 20.2 & 2.49 & 0.44 & 0.98 & 0.96 & 1.23 & 0.69 & 1.44 & 3.60 & 2.50 & 6.10 & 1.8 & 2.9 & $3+$ & 21.8 & 31.5 & 232 & 95 \\
\hline T.T. & 37.8 & 8.8 & 16.3 & 21.0 & 16.1 & 2.47 & 0.57 & 1.06 & 2.37 & 1.05 & 0.61 & 1.19 & 3.54 & 2.98 & 6.52 & 3.5 & 4.6 & $1+$ & 9.2 & 12.3 & 268 & 165 \\
\hline K.T. & 36.9 & 6.9 & 12.1 & 23.7 & 20.4 & 2.03 & 0.38 & 0.67 & 1.30 & 1.12 & 0.59 & 1.08 & 2.86 & 2.64 & 5.50 & 12.0 & 17.2 & $3+$ & 12.7 & 10.4 & 400 & 60 \\
\hline M.E. & 39.0 & 6.6 & 9.4 & 18.8 & 26.2 & 3.12 & 0.53 & 0.75 & 1.50 & 2.10 & 0.6 & 0.98 & 3.95 & 4.05 & 8.00 & 0.9 & 1.7 & $4+$ & 28.8 & 41.7 & 350 & 245 \\
\hline I.8. & 29.6 & 5.3 & 9.3 & 25.6 & 30.2 & 2.53 & 0.45 & 0.79 & 2.19 & 2.58 & 0.42 & 0.72 & 3.58 & 4.96 & 8.54 & 2.3 & 3.2 & $3+$ & 15.0 & 49.9 & 470 & 225 \\
\hline I.I. & 32.4 & 6.0 & 10.9 & 32.7 & 18.0 & 2.92 & 0.54 & 0.99 & 2.95 & 2.63 & 0.48 & 0.80 & 4.00 & 5.03 & 9.03 & 12.1 & 16.3 & $4+$ & 20.0 & 63.4 & 408 & 245 \\
\hline AVERACS & 40.6 & 6.2 & 21.6 & 22.0 & 19.6 & 2.89 & 0.44 & 0.81 & 1.60 & 1.44 & 0.71 & 1.29 & 3.89 & 3.29 & 7.18 & & & & & & & \\
\hline $\begin{array}{l}\text { Standary } \\
\text { Dorleticon }\end{array}$ & 6.9 & 2.3 & 4.0 & 5.2 & 5.6 & 0.52 & 0.08 & 0.21 & 0.55 & 0.55 & 0.21 & 0.41 & 0.48 & 0.99 & 1.06 & & & & & & & \\
\hline
\end{tabular}

LORAT BitRA

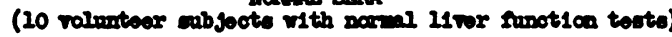

\begin{tabular}{|l|c|c|c|c|c||c|c|c|c|c|c|c|c|c|c|}
\hline AVERAC: & 60.3 & 4.0 & 9.7 & 12.8 & 13.2 & 4.23 & 0.28 & 0.68 & 0.89 & 0.93 & 1.52 & 2.31 & 4.89 & 2.12 & 7.01 \\
\hline $\begin{array}{l}\text { Etandard } \\
\text { Dorlation }\end{array}$ & 2.8 & 0.8 & 1.5 & 1.2 & 1.7 & 0.29 & 0.06 & 0.10 & 0.08 & 0.13 & 0.28 & 0.34 & 0.30 & 0.24 & 0.30 \\
\hline
\end{tabular}

even when normal by the Howe method. The gamma-globulins were elevated in eight of the ten cases. The beta-globulins were elevated in all cases, with some strikingly high values, a finding which will be further discussed. Significant increases of the alpha-one- and alpha-two-globulins occurred less frequently.

As shown in Table I, hypercholesterolemia with decreased cholesterol esters was observed although not a constant finding. Several unusually high alkaline phosphatase activities occurred, and all but two values were above normal. Cephalin cholesterol flocculation and thymol turbidity tests were positive in all but four and two instances respectively.

On the basis of their clinical status at the time of the study, the cases fell into three groups which bore some relationship to the electrophoretic data.

In the first group of two cases (W. H. and $M$. F.) the pathologic process was apparently quiescent and the serum bilirubin values were normal. W. $H$. had been entirely asymptomatic for five months with normal tests of hepatic function including bromsulfalein retention of 3 per cent; the electrophoretic analysis showed slightly reduced albumin, elevated beta-globulin, and normal gamma-globulin. M. F. with minimal symptoms (pruritus, fatigability) for 11 months had a high alkaline phosphatase (35.1 units) and bromsulfalein retention of 48 per cent, despite normal serum bilirubin; the electrophoretic analysis revealed moderately diminished albumin and elevated betaand gamma-globulins.

The second group of five patients (T. O., M. G., C. M., F. F., and K. V.) had active ascending cholangitis at the time of the study with varying degrees of elevation of the serum bilirubin. The electrophoretic patterns showed greater deviation from the normal than the quiescent group with, however, considerable variation. The albumin values of all but one (M. G.) were below 3 grams per cent. T. O. exhibited a strikingly high betaglobulin peak without gamma-globulin increase. M. G. and K. V. showed increased beta- and 
gamma-globulins. C. M. and F. F. had some elevation of all the globulin fractions, the former with high gamma-globulin, the latter with high betaglobulin.

The third group of three patients (M. E., L. S., and L. H.) exhibited secondary xanthomatosis (palmar and palpebral) after long histories of obstructive jaundice. M. E. was studied three years after the onset of episodes of chills, fever and jaundice, and five months after cholecystectomy which had been followed by decline of the serum bilirubin to a value only slightly above the normal range. The electrophoretic analysis showed marked abnormality with diminished albumin and elevated beta- and gamma-globulins, but the pattern was far less striking than those of L. S. and L. H., the most bizarre in the series. These patients had almost complete occlusion of the common duct due to stricture following cholecystectomy five years ago in each case, and attempts at operative repair had been futile. The onset of progressive secondary xanthomatosis occurred during periods of clinical observation long after histologic diagnoses of obstructive biliary cirrhosis had been made. The electrophoretic patterns showed spectacular beta-globulin elevations. Both had marked diminutions of the albumin fractions. The beta-globulin fraction of L. S. was exceeded by the even higher gamma globulin, which was the highest in all the cases studied. The beta-globulin of $\mathrm{L}$. $\mathrm{H}$. was over three times the normal in grams per cent and exceeded each of the other fractions of the serum.

Changes of electrophoretic patterns during the course of the disease were followed in three illustrative cases (K. V., L. S., and L. H.). All were given a high protein, high carbohydrate and high caloric diet containing 120 to 150 grams of protein, 350 to 450 grams of carbohydrate, a total of 3,000 to 3,500 calories, supplemented by 4 to

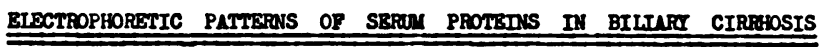

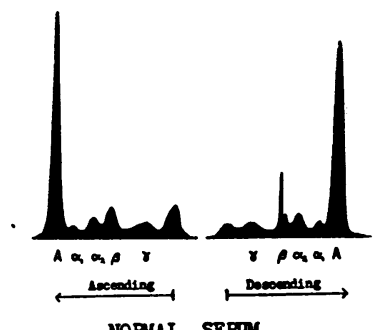

NORUL SERW

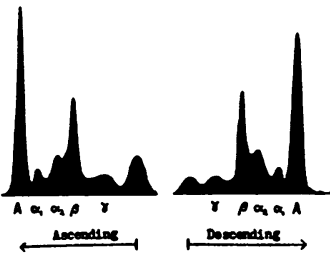

T.0. - Diminished alburin; elevated beta-globulin without gamma-globulin increase.

Active ascending cholangtis and intense jaundice.

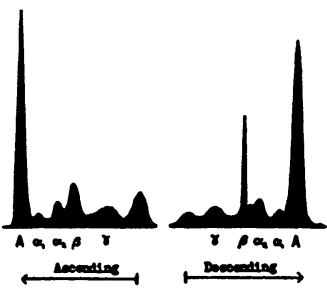
T.H. - Slightly diminished albumin and Asymptomatic for 5 months. Normal serum bilirubin and tests of hepatic runction.

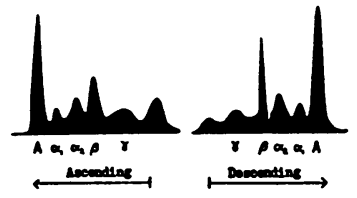

F.F. - Diminished albumin; ail globulin fractions elevated, especially betaglobalin.

Active ascending cholangtis and intense jaundice.

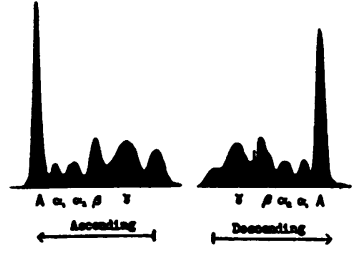

U.B. - Diminished albumin; elevated beta- and gamnaglobalins.

ictive ascending cholangtis, jaundice, and biliary cirthosis before cholecystectory. Secondary toctory. Secondary xanthoserum bilinubin.

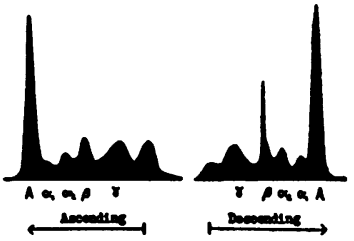

U.P. - Diminished albumin; elevated betra - and gammaelevated beth globulins. months. Hormal serum bilirubin but high alkaline phosphatase and bromoulfales retention.

FIG. 1

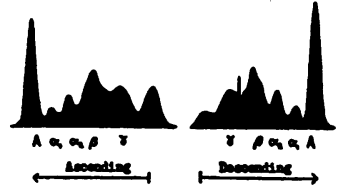

L.H. - Diminished albunin; elevated globulins. Betaglobulin exceeds all other fractions. Stricture of cownon duct after cholecystectouy. ICtive ascending cholangits and intense jaundice. Secveloped subsequently.

The albumin peaks are indicated by "A," and the globulins by their respective Greek letter prefixes. The unlabelled peaks are the stationary anomalous boundaries due to gradients of buffer salt. 
TABLE II

COURST OF BIITART CTRRBOSTS

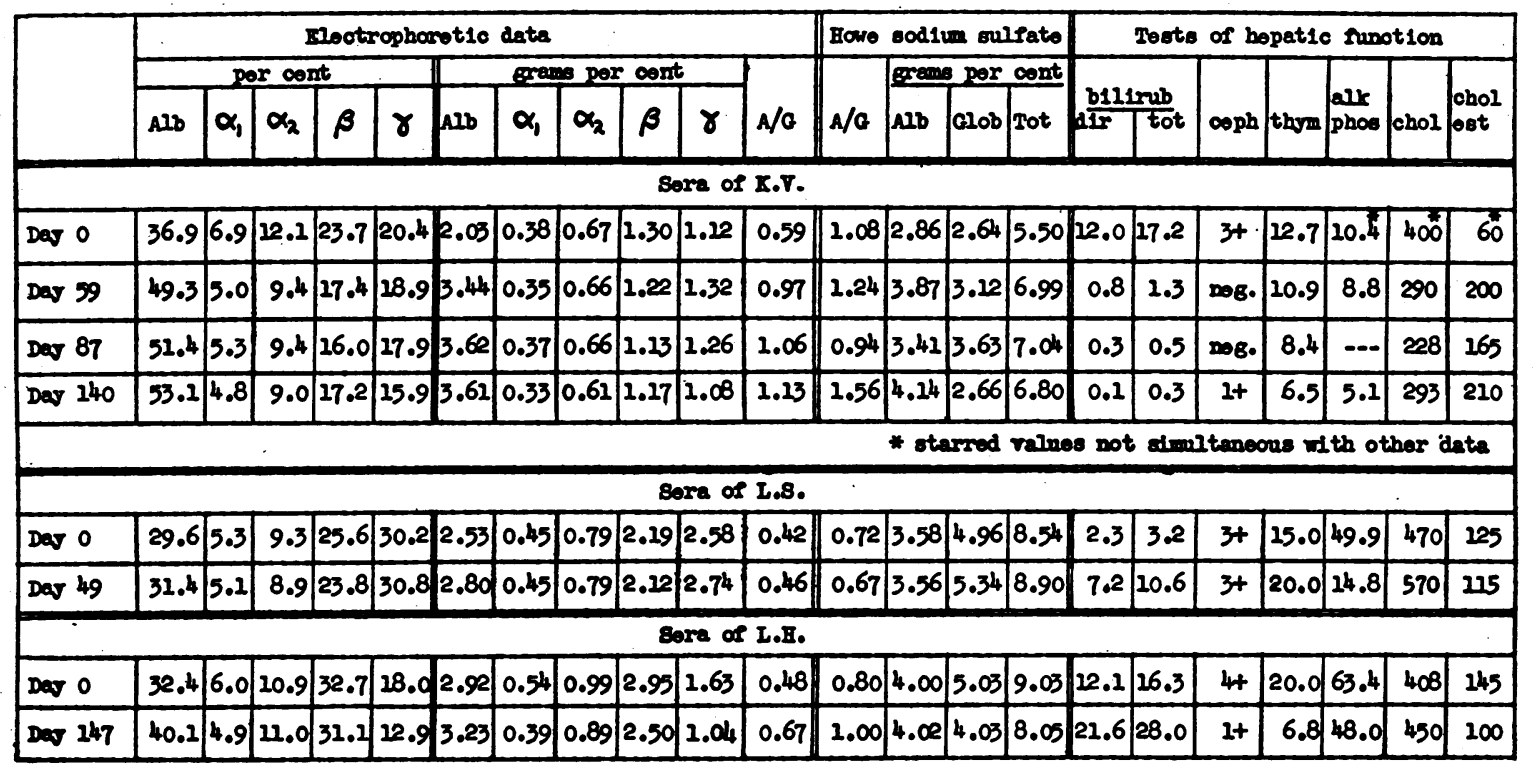

\section{COURSE OF BILTAR CIRRAOSIS}

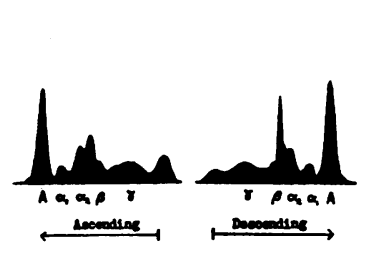

Daro

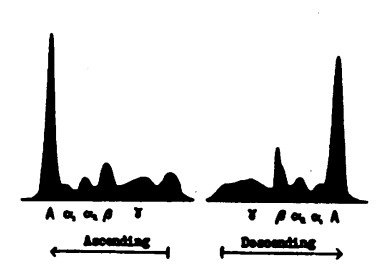

Der 59

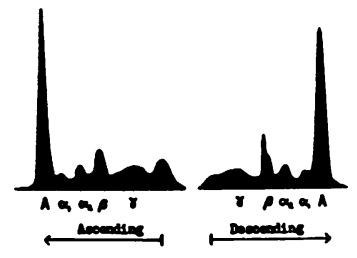

Dey 87

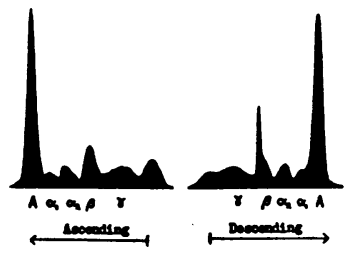

Day 210

I. V. - Cholocystectomy with rubber abdominal drain throe months previously followed by intense faundice and accending cholangitis. Insertian of I-tube into ollghtis dilated counon duct. Subsidence of jaundice and all aymotoms.

ilteration of electrophoretic pattern in the direction of norral by Day 59; 21 ttile change thereafter.

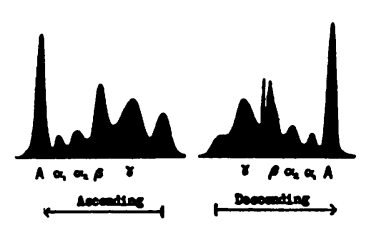

$\underline{\operatorname{Dar} 0}$
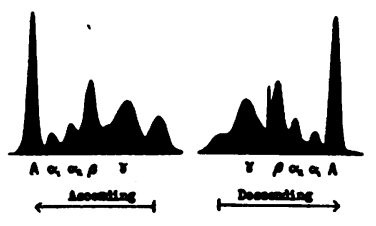

Der 49

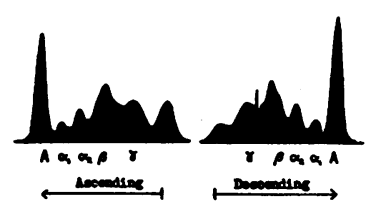

Dar 0

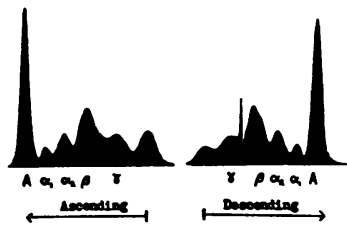

Dar 147

I.S. - Irreparable stricture of common duct after cholecystectouy five years ago. Progressive development of secondary canthomatosis.

No significant change in electrophoretic pattern.

FIG. 2

L.H. - Irreparable etricture of common duct after cholecystectony flve years ago. Progressive development of secondary xanthomatosis.

iittle change in electrophoretic pattern. 
Mopand SERar

Figures are arerages of ten volunteor subjects with norial tests of hepatic function.

\begin{tabular}{lc|c|c|c|c|c} 
& $\mu \mathrm{b}$ & $\alpha_{1}$ & $\alpha_{2}$ & $\beta$ & $\gamma$ & $\mu / \theta$ \\
\hline per cent & 60.3 & 4.0 & 9.7 & 12.8 & 23.2 & 1.52 \\
\hline Erams per cent & 4.23 & 0.28 & 0.68 & 0.89 & 0.93 & \\
\hline Howe sod. sulfate & 4.89 & $030 b-2.12$ & Tot-7.01 & 2.31 \\
\hline
\end{tabular}

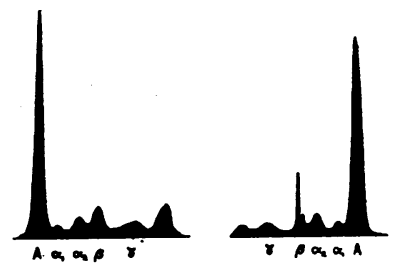

\section{PORCII CIRRETOSTS}

Intense jaundice, massive ascites and edema in patient with advanced portal cirrtosis (noedile biopsy).

\begin{tabular}{lc|c|c|c|c|c} 
& $\mu \mathrm{b}$ & $\alpha_{1}$ & $\alpha_{2}$ & $\beta$ & $\gamma$ & $\mu / \mathrm{V}$ \\
\hline per cent & 38.1 & 4.1 & 6.4 & 12.6 & 38.8 & 0.62 \\
\hline grams per cent & 2.56 & 0.28 & 0.43 & 0.85 & 2.62 & \\
\hline Howe sod. sulfate & 2.99 & G10b-3.74 & Tot-6.73 & 0.80
\end{tabular}

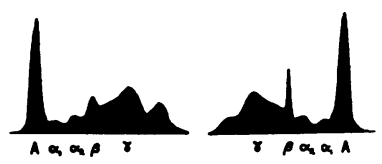

\section{BILTARI CIRRETOSIS}

L.H. - Irreparable strictare of comon dnct after cholocystectouy 5 years ago. Intense jaundice. Socondary canthomatosis.

\begin{tabular}{|c|c|c|c|c|c|c|}
\hline & $\mu \mathrm{b}$ & $\alpha_{1}$ & $\alpha_{2}$ & $\boldsymbol{\beta}$ & $\gamma$ & $N / O$ \\
\hline per cent & 40.1 & 4.9 & 21.0 & 31.2 & 12.9 & 0.67 \\
\hline ans per cent & 3.23 & 0.39 & 0.89 & 2.50 & 1.04 & \\
\hline dowe sod. sulfate & 4.021 & Giob & & Tot & -8.05 & 1.00 \\
\hline
\end{tabular}

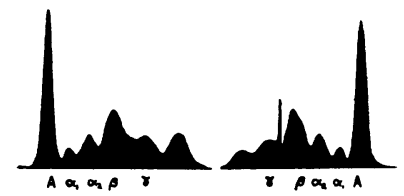

\section{BIITART CIREROSIS

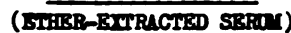

Same sercm as above after three extractions with redistililed diethol ether.

\begin{tabular}{|c|c|c|c|c|c|c|}
\hline & $\Delta \mathrm{b}$ & $\alpha_{1}$ & $\alpha_{2}$ & $\boldsymbol{\beta}$ & $\gamma$ & |No \\
\hline ser cent & 44.8 & 5.2 & 13.2 & 4.5 & 22.3 & 0.81 \\
\hline
\end{tabular}

Beta-globulin peak recuced to epproximately one thind of original area.

FIG. 3

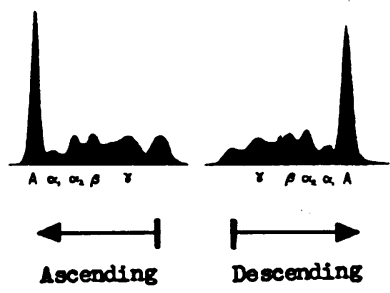

6 grams of choline chloride daily. During periods of acute ascending cholangitis sulfadiazine and/or penicillin was administered.

The electrophoretic patterns and data of these three patients are shown in Figure 2 and Table II.

K. V. had had a cholecystectomy three months previously with a rubber abdominal drain left in place, followed by intense jaundice and ascending cholangitis. After laparotomy with insertion of a $T$-tube into the slightly dilated common duct (ten days prior to Day 0 ) the jaundice and all symptoms subsided. The serial electrophoretic patterns showed evolution in the direction of normal with definite rise of the diminished albumin fraction and some decline of the elevated beta- and gammaglobulins. The most pronounced change had occurred by Day 59, the pattern showing only minor alteration thereafter. During the period of study there was also change of the tests of hepatic function toward normal.

L. S. and L. H. with irreversible obstructive jaundice (severe stricture of the common duct) and secondary xanthomatosis manifested no fundamental change in clinical status during observation, although recurring episodes of acute ascending cholangitis with chills and fever were prevented by sulfadiazine ( 2 to 6 grams daily). The electrophoretic pattern of L. S. showed no 
significant change after 49 days. After 147 days, L. H. exhibited some albumin rise and decline of the elevated gamma-globulin, while the pattern retained the same bizarre general configuration with the striking beta-globulin peak.

In contrast with these findings, portal cirrhosis has not shown marked elevation of the beta-globulin fraction as a constant or conspicuous feature. Comparison of the electrophoretic patterns of deeply jaundiced cases of biliary and portal cirrhosis is illustrated in Figure 3 where the difference between the beta-globulin peaks is striking.

Ether extraction of the serum of the case of biliary cirrhosis resulted in pronounced reduction of the beta-globulin peak to approximately onethird its original area, the conspicuous beta-globulin disturbance (spike) of the descending pattern being likewise markedly diminished. This experiment indicates the important contribution of lipo-protein to the high beta-globulin.

\section{DISCUSSION}

The ten cases of biliary cirrhosis had diminished albumin values in all instances, even when normal by the Howe method. The gamma-globulins were elevated in eight of the ten cases. The most characteristic and conspicuous feature, however, was elevation of the beta-globulins, observed in all cases and reaching spectacular levels in two cases with secondary xanthomatosis (L. S. and L. H.). These two cases with almost complete occlusion of the common duct due to post-operative stricture of five years' duration exhibited the most abnormal electrophoretic patterns of the series, one of them (L. H.) showing a beta-globulin exceeding any of the other fractions. The electrophoretic pattern nearest normal occurred in a patient (W. H.) who had been entirely asymptomatic for five months and had normal tests of hepatic function. This pattern revealed slightly diminished albumin, elevated beta-globulin and normal gamma-globulin.

The data in these cases of biliary cirrhosis contrasted with the findings in a previously reported series of cases of portal cirrhosis (4) in which elevation of the beta-globulin fraction was a less constant and less conspicuous feature, strikingly tall peaks never having been observed even when the beta-globulin was high. Moreover, in the cases of portal cirrhosis beta-globulin increases did not occur without marked elevation of gammaglobulin.

It is of interest to compare these findings with the isolated cases previously reported. The patient with "xanthomatosis and biliary cirrhosis" of Gray and Barron (1) exhibited a serum protein composition strikingly similar to our cases with secondary xanthomatosis. The two cases of Thorn, Armstrong and Davenport (2) had major concomitant disease : in one, the biliary cirrhosis was secondary to bile duct carcinoma extensively infiltrating the liver, and in the other biliary cirrhosis was superimposed on old portal cirrhosis, the electrophoretic analyses showing slightly elevated and normal beta-globulins respectively. The patients evidently do not bear close comparison with the present series. A single case listed among the data of Cohen and Thompson (3) had only slight elevation of the beta-globulin but a very high gamma-globulin.

The experiment showing reduction of the greatly increased beta-globulin peak to approximately onethird its original area by ether extraction was interpreted as demonstrating the important contribution of lipo-protein to this pathologically elevated fraction. The same phenomenon has been observed by Longsworth and colleagues in sera of patients with nephrosis (9) and obstructive jaundice (10), the one difference being that the descending beta-globulin disturbance (spike) was essentially unchanged, whereas in the present experiment it was markedly diminished after ether extraction. Zeldis, Alling and co-workers (11) reported somewhat similar results but with complete abolition of the beta-globulin disturbance employing an alcohol-ether extraction that probably caused partial denaturation of the proteins. These findings were obtained in patients with nephrosis, "obstructive jaundice with cholangitis," and other diseases. Unpublished work by Lever (12) corroborates and extends the present findings with cold ether extraction.

Longsworth (9) has discussed the distinction between the lipids presumably present as suspended globules coated with beta-globulin, notably in lipemic (milky) sera which can be clarified by high speed centrifugation, and on the other hand the lipo-proteins in clear solution, which in pathologic sera (such as the present series) may be extracted by cold ether with reduction of the 
abnormally high beta-globulin peak. It should be noted that the alpha- and beta-lipo-proteins of normal sera have the solubility properties of proteins $(13,14)$ and are not ether-extractable to any extent $(9,14)$. The present elevated betalipo-protein may differ essentially from the normal. An alternative suggestion is the possible effect of bile salts in the serum on the stability of the lipo-protein complex $(15,16)$.

Kunkel and Ahrens $(17,18)$ have emphasized the role of the phospholipid content of the lipoproteins. The phospholipids were found to be relatively low in the lipemic (milky) sera of patients with nephrosis, but high in the transparent high-lipid sera of patients with biliary cirrhosis. The clarity of the high-lipid sera in biliary cirrhosis was attributed to the hydrophilic nature of the phospholipids by virtue of their water-soluble side chains.

Whether the elevated lipo-protein observed electrophoretically as a high beta-globulin peak is merely a phenomenon of biliary regurgitation or whether it represents some derangement of hepatic metabolism remains to be determined. The patterns with high beta-globulin peaks reported by Longsworth (10) and Zeldis and Alling (11) in "obstructive jaundice" tend to support the former view, but further knowledge of hepatic function in these cases would be needed. Gray and Barron (1) emphasized that jaundice per se has no influence on the electrophoretic pattern and presented five jaundiced cases of common duct stone, four of which exhibited normal serum proteins. The remaining case had an elevated beta-globulin fraction, but laparotomy biopsy of the liver showed marked histologic evidence of parenchymal damage. Conversely, in the present series, two cases (W. H. and M. F. with apparently quiescent pathologic processes) showed elevated beta-globulins in the presence of normal serum bilirubin.

The observations of Balfour (19) with the aid of radioactive phosphorus together with previous data (20) suggest that in patients with high levels of plasma lipids the cause of elevated phospholipids is overproduction by the liver rather than biliary regurgitation, not only in biliary cirrhosis but also in the nephrotic syndrome and other conditions.

In the present study the serial electrophoretic analyses on sera from a patient without serious mechanical obstruction showed alteration of the serum proteins in the direction of normal coinciding with clinical improvement, as has been observed previously in patients with portal cirrhosis under medical management (21). On the other hand, as expected, two patients with irreparable stricture of the common duct showed little change in electrophoretic pattern during the period of observation.

\section{SUM MARY}

1. Electrophoretic analyses of the serum proteins of ten cases of biliary cirrhosis of the obstructive type revealed deviations from the normal composition in all.

2. The albumin fractions were diminished in all cases and the gamma-globulins were elevated in eight of the ten cases.

3. Elevated beta-globulins were found in all cases and were sometimes strikingly increased.

4. The elevation of beta-globulins was attributed to increased lipo-protein.

5. The abnormalities of the serum proteins were greatest in two cases with irreparable postoperative stricture of the common duct and secondary xanthomatosis, and were minimal in a case without clinical symptoms at the time of study.

\section{ACKNOWLEDGMENTS}

The authors wish to express their gratitude to Dr. E. S. Guzman Barron for making available the electrophoresis apparatus used in this study, and also their indebtedness to Robert S. Levine for his invaluable technical assistance with the tests of hepatic function.

\section{BIBLIOGRAPHY}

1. Gray, S. J., and Barron, E. S. G., The electrophoretic analyses of the serum proteins in diseases of the liver. J. Clin. Invest., 1943, 22, 191.

2. Thorn, G. W., Armstrong, S. H., Jr., and Davenport, V. D., Chemical, clinical, and immunological studies on the products of human plasma fractionation. XXXI. The use of salt-poor concentrated human serum albumin solution in the treatment of hepatic cirrhosis. J. Clin. Invest., 1946, 25, 304.

3. Cohen, P. P., and Thompson, F. L., Mechanism of the thymol turbidity test. J. Lab. \& Clin. Med., 1947, 32, 475.

4a. Ricketts, W. E., Sterling, K., Kirsner, J. B., and Palmer, W. L., Electrophoretic studies of the serum proteins in portal cirrhosis. Gastroenterology, in press. 
4b. Sterling, K., The serum proteins in infectious mononucleosis. Electrophoretic studies. J. Clin. Invest., 1949, 28, 1057.

5. Dole, V. P., The electrophoretic patterns of normal plasma. J. Clin. Invest., 1944, 23, 708.

6. Armstrong, S. H., Jr., Budka, M. J. E., and Morrison, K. C., Preparation and properties of serum and plasma proteins. XI. Quantitative interpretation of electrophoretic schlieren diagrams of normal human plasma proteins. J. Am. Chem. Soc., 1947, 69, 416.

7. Armstrong, S. H., Jr., Budka, M. J. E., Morrison, K. C., and Hasson, M., Preparation and properties of serum and plasma proteins. XII. The refractive properties of the proteins of human plasma and certain purified fractions. J. Am. Chem. Soc., 1947, 69, 1747.

8. Schoenheimer, R., and Sperry, W: M., A micromethod for the determination of free and combined cholesterol. J. Biol. Chem., 1934, 106, 745.

9. Longsworth, L. G., and MacInnes, D. A., An electrophoretic study of nephrotic sera and urine. J. Exper. Med., 1940, 71, 77.

10. Longsworth, L. G., Shedlovsky, T., and MacInnes, D. A., Electrophoretic patterns of normal and pathological human blood serum and plasma. J. Exper. Med., 1939, 70, 399.

11. Zeldis, L. J., Alling, E. L., McCoord, A. B., and Kulka, J. P., Plasma protein metabolism-electrophoretic studies. The influence of plasma lipids on electrophoretic patterns of human and dog plasma. J. Exper. Med., 1945, 82, 411.
12. Lever, W., Personal communication.

13. Gurd, F. R. N., Oncley, J. L., Edsall, J. T., and Cohn, E. J., The lipo-proteins of human plasma. Trans. Faraday Soc., in press.

14. Oncley, J. L., Gurd, F. R. N., and Melin, M., Preparation and properties of serum and plasma proteins. XXV. Composition and properties of human serum $\beta$-lipoprotein. In preparation.

15. Tayeau, F., Le système lipidoprotéidique du sérum sanguin chez les malades atteints d'ictère par rétention. Compt. rend Soc. de Biol., 1943, 137, 240.

16. Tayeau, F., Action des sals biliares en présence d'ether sur les cénapses lipidoprotéidiques du sérum sanguin. Bull. Soc. chim. biol., 1944, 26, 295.

17. Kunkel, H. G., Personal communication.

18. Ahrens, E. H., Jr., and Kunkel, H. G., The role of phopholipids in high-lipid sera in cirrhosis and nephrosis. J. Clin. Invest., 1949, 28, 767.

19. Balfour, W. M., Human plasma phospholipid formation; a study made with the aid of radiophosphorus. Gastroenterology, 1947, 9, 686.

20. Fishler, M. C., Entenman, G., Montgomery, M. L., and Chaikoff, I. L., The formation of phospholipid by the hepatectomized dog as measured with radioactive phosphorus. I. The site of formation of plasma phospholipids. J. Biol. Chem., 1943, 150, 47.

21. Sterling, K., Ricketts, W. E., Kirsner, J. B., and Palmer, W. L., The serum proteins in portal cirrhosis under medical management. Electrophoretic studies. J. Clin. Invest., 1949, 28, 1236. 